NBER WORKING PAPER SERIES

\title{
PAROCHIAL INTERESTS AND THE CENTRALIZED \\ PROVISION OF LOCAL PUBLIC GOODS: EVIDENCE FROM CONGRESSIONAL VOTING \\ ON TRANSPORTATION PROJECTS
}

\author{
Brian Knight \\ Working Paper 9748 \\ http://www.nber.org/papers/w9748 \\ NATIONAL BUREAU OF ECONOMIC RESEARCH \\ 1050 Massachusetts Avenue \\ Cambridge, MA 02138 \\ June 2003
}

An earlier version of this paper was titled "The Advantages and Disadvantages of Centralized Provision of Public Goods: Evidence from Congressional Voting on Transportation Projects". Jim Andreoni, Reza Baqir, Moshe Buchinsky, Victor Davis, Jonah Gelbach, Mike Hanmer, Bob Inman, John Straub, and Koleman Strumpf provided helpful comments. The views expressed herein are those of the authors and not necessarily those of the National Bureau of Economic Research.

C2003 by Brian Knight. All rights reserved. Short sections of text not to exceed two paragraphs, may be quoted without explicit permission provided that full credit including (C) notice, is given to the source. 
Parochial Interests and the Centralized Provision of Local Public Goods: Evidence from Congressional Voting on Transportation Projects

Brian Knight

NBER Working Paper No. 9748

June 2003

JEL No. H4, H7, D7

\begin{abstract}
$\underline{\text { ABSTRACT }}$
Local public goods financed from a national tax base provide concentrated benefits to receipient jurisdictions but disperse costs, creating incentives for legislators to increase own-district spending but to restrain aggregate spending due to the associated tax costs. While these common pool incentives underpin a variety of theoretical analyses, which tend to predict inefficiencies in the allocation of public goods, there is little direct evidence that individual legislators respond to such incentives. To test for reactions to such incentives, this paper analyzes 1998 Congressional votes over transportation project funding. The empirical results provide evidence that legislators respond to common pool incentives: the probability of supporting the projects is increasing in own-district spending and decreasing in the tax burden associated with aggregate spending. Having found that legislators do respond to such incentives, I use the parameter estimates to calculate the efficient level of public goods, which suggest over-spending in aggregate, especially in politically powerful districts, and large associated deadweight loss.
\end{abstract}

\author{
Brian Knight \\ Department of Economics \\ Brown University, Box B \\ Providence, RI 02912 \\ and NBER \\ Brian_Knight@Brown.edu
}


"Mississippi is getting tired of dirt roads; we want some asphalt."

Sen. Trent Lott (R, Mississippi), CQ Almanac, 1998

"The only guarantee that donor states should expect from this legislation is that they will continue to subsidize road projects in other states"

Sen. John McCain (R, Arizona), CQ Almanac, 1998

\section{Introduction}

In the United States, the federal government provides funding for many types of public goods that are primarily local in nature. Examples include highways, bridges, water projects, and airports. Such spending programs provide geographically concentrated benefits to recipient jurisdictions but disperse costs due to a national, or common pool, tax base. In central legislatures with locally-elected representatives, such as the U.S. Congress, this geographic disconnect between program benefits and costs creates incentives for legislators to increase own-district spending because the district bears only a small share of the associated tax costs. Countering this bias towards higher spending, each legislator has an incentive to restrain spending in other districts due to the associated tax costs.

This characteristic of centrally-provided local public goods, concentrated benefits and dispersed tax costs, is central to models of legislative behavior. Weingast, Shepsle and Johnson (1981) focus on the first incentive created by common pool tax bases, namely the preference to expand own-district spending. In their model, legislatures operate according to a cooperative, or universalistic, norm under which each legislator independently chooses own-district spending, leading to inefficiently high spending in every district and hence in aggregate. In non-cooperative models of legislative bargaining, such as that of Baron and Ferejohn (1987 and 1989), both the incentives to expand own-district spending and to restrain aggregate spending are present, and the legislative outcome is one in which public spending is misallocated: public goods are over-provided in jurisdictions with political power and under-provided elsewhere. The recent literature on political federalism has applied these models of legislature behavior in order to re-address a classic question in public economics: within a federation, which level of government should provide public goods? By incorporating spillovers into these models of legislative behavior, this literature has identified a trade-off between the ability of centralized governments to internalize cross-jurisdiction spillovers and its tendency towards pork-barrel over-spending, particularly in politically powerful districts. ${ }^{1}$

\footnotetext{
${ }^{1}$ See Inman and Rubinfeld (1997a, 1997b), Besley and Coate (2003), and Lockwood (2002).
} 
While the incentives created by national financing of local public goods underpin these theoretical analyses, there is little direct evidence that legislators respond to such incentives. In order to test for such common pool incentives, this paper uses 1998 Congressional votes over transportation project funding; this empirical voting analysis is shown to be consistent with the two most commonly-used legislative processes in the theoretical literature and is thus quite general. The empirical results demonstrate that legislator choices reflect these common pool incentives: the probability of supporting funding for the projects is increasing in own-district spending and decreasing in the tax burden associated with aggregate spending. These results are robust to several alternative specifications, although the tax cost relationship is statistically insignificant in several cases. Having found that legislators do respond to such incentives, I then estimate the underlying theoretical parameters and use these in order to calculate the degree of inefficiency associated with the common pool problem. These calculations suggest over-spending in aggregate, particularly in politically powerful districts, and large associated deadweight loss.

\section{Related literature}

The vast majority of empirical research on common tax pool incentives has used legislatures as the empirical unit of analysis. Inman (1988) attempts to measure the over-provision of federal grants in the U.S. Congress by using a 1972 shift in Congressional norms from one of decisionmaking by strong political parties towards one of decentralized decision-making in which each legislator internalizes only his district's share of the tax costs. Inman attributes a significant portion of the increase in grants after 1972 to this shift and predicts that a decentralized Congress would have spent almost 50 percent less were they forced to fully internalize tax costs, implying a deadweight loss of 17 cents for every dollar allocated. A related literature uses variation in the size of legislatures, and hence the degree of the common pool problem, across municipalities (Baqir, 2002), U.S. states (Gilligan and Matsusaka, 1995 and Crain, 1999), and countries (Bradbury and Crain, 2001). These studies have documented a positive relationship between the size of legislatures and government spending.

Since these analyses rely on both a specification of the legislative process and maintained behavioral assumptions on the part of legislators, analyses at the legislator level, which rely on less stringent assumptions, are a useful complement. The only such analysis of which I am aware is DelRossi and Inman (1999), who use variation in local cost sharing rules for water projects to gauge the extent to which legislator demands for spending respond to the share financed by the federal government. The estimated price elasticity of demand is large, ranging from -0.81 to -2.55 . Relative to DelRossi and Inman, my paper makes several contri- 
butions. First, while DelRossi and Inman focus on the first incentive created by a common tax pool, namely a preference to expand own-district spending due to common pool tax bases, my analysis incorporates both this first incentive as well as a second key incentive, a preference to restrain aggregate spending due to the associated tax liabilities. Second, I provide a welfare analysis, which includes estimates of the efficient allocation of public goods and the deadweight loss associated with this common pool problem. Finally, while the analysis of DelRossi and Inman relies on exogenous policy shocks, my methodology, which can be implemented using widely-available data on voting records and the benefits and costs of legislation, has broader application.

This paper is also related to a broader literature on the determinants of roll-call voting behavior in Congress. Peltzman (1985) finds that, after controlling for persistent regional differences in ideology, Senators from states reaping the largest net benefits from federal spending programs were more likely to support expansions of such programs, as captured by an aggregate voting index constructed by the National Taxpayers Union. In an examination of the electoral benefits of securing pork, Sellers (1997) finds an interesting interaction between Congressional voting records and pork. In districts receiving substantial pork, incumbents with fiscally liberal voting records perform better electorally than do fiscal conservatives. In low-pork districts, by contrast, fiscal conservatives perform better. Stein and Bickers (1995) note that, while many federal spending programs are concentrated in a minority of Congressional districts, such programs are often approved by overwhelming majorities in Congress. They argue that, in order to guarantee passage, special interest groups benefiting from such programs tend to make campaign contributions to a large group of representatives. Poole and Rosenthal (1997) downplay the role of economic factors, arguing that a single dimension, which can be interpreted as ideology, explains nearly all of variation in roll-call votes in Congress since the 1970s.

\section{Theoretical Framework}

This theoretical section serves two purposes. First, it formally documents the common pool incentives facing legislators to increase own-district spending but to restrain aggregate spending. Second, the theoretical model provides a framework for measuring legislator responses to such incentives. Given this empirical focus, the model is kept simple, focusing on local public goods funded from a national tax base and abstracting from other potentially important factors in the centralized provision of local public goods, such as spillovers, heterogeneity in preferences, and economies of scale. 


\subsection{Setup}

Consider a legislature with $J$ (odd) members, or jurisdictions, which are indexed by $j$ and are of equal population $N .^{2}$ The economy has $J+1$ goods, a private good $(c)$ and a vector of local public goods $\left[\mathbf{g}=\left(g_{1}, g_{2}, \ldots, g_{J}\right)\right]$, one for each jurisdiction. For simplicity, individual preferences are assumed identical within and across jurisdictions. Individual utility over the local public good and private goods is assumed quasi-linear:

$$
U\left(g_{j}, c_{i j}\right)=h\left(g_{j}\right)+c_{i j}
$$

Utility from local public goods $\left[h\left(g_{j}\right)\right]$ is assumed increasing and concave and is normalized such that zero utility is obtained from zero spending $[h(0)=0]$. Finally, each resident in jurisdiction $j$ is endowed with $m_{j}$ units of the private good, which can be converted into public goods at a dollar-for-dollar rate.

Given this setup, consider a normative benchmark, which will be used to evaluate the performance of centralized governments in providing public goods. The Samuelson provision of public projects $\left(g_{j}^{S}\right)$ can be characterized as follows:

$$
N h^{\prime}\left(g_{j}^{S}\right)=1, \quad j=1,2, \ldots, J
$$

This expression equates the total willingness to pay across constituents to the marginal cost of provision. While the Samuelson level of public goods would be that chosen by a national planner, centralized legislatures consist of elected representatives, who face incentives to serve local, rather than national, interests. The remainder of this section documents the effects of this divergence between national and local interests on the level and cross-jurisdiction allocation of public goods.

A key feature of centralized provision is that tax financing is assumed to be shared equally across the federation. That is, total jurisdiction tax liabilities are given by $\tau=\frac{G}{J}$, where $G$ is total federal public spending. This common pool feature of centralized tax systems will play an important role below.

A legislature, consisting of one representative from each jurisdiction, chooses both the aggregate supply of public goods $(G)$ as well as the distribution of this budget across jurisdictions. I abstract from agency considerations and simply assume that each representative seeks to maximize the utility of a representative constituent:

\footnotetext{
${ }^{2}$ The equal population assumption is reasonable in this empirical analysis of Congressional districts, which are partioned according to population.
} 


$$
U\left(g_{j}, \mathbf{g}_{-j}\right)=h\left(g_{j}\right)+m_{j}-\frac{G}{N J}
$$

I next consider two commonly-studied political processes in the theoretical literature: legislative bargaining and universalism.

\subsection{Legislative bargaining}

Consider first a two-stage version of the legislative bargaining model due to Baron and Ferejohn (1987 and 1989). ${ }^{3}$ In the first stage, an agenda-setter $(j=a)$, whose identity is determined exogenously, proposes a distribution of public spending $\left(\mathrm{g}^{L}\right)$. In the second stage, each legislator votes on the proposed budget. If the proposal receives a majority of votes, it is implemented; otherwise, a reversion distribution of zero spending is implemented $\left(\mathbf{g}^{R}=\mathbf{0}\right)$.

Using the normalization that constituents receive zero utility from public goods under the reversion budget $[h(0)=0]$, legislators will support the proposal if the total benefits accruing to the district exceed its share of the tax costs:

$$
h\left(g_{j}^{L}\right) \geq \tau / N
$$

Incorporating the voting rule of each legislator, given in equation 4 , the proposer will maximize the utility of his representative constituent, subject to the constraint that at least $\frac{J-1}{2}$ other representatives support the proposal. Given majority rule and the common pool tax base $(\tau=G / J)$, the proposer has an incentive to form a majority coalition $M$, not including the proposer, of minimum size $\frac{J-1}{2}$. This optimal proposal $\left(\mathbf{g}^{L}\right)$ can be characterized as follows:

$$
\begin{gathered}
N h^{\prime}\left(g_{j}^{L}\right)=\left[\frac{1}{J}+\frac{\lambda}{J} \times \frac{(J-1)}{2}\right], \quad j=a \\
\lambda N h^{\prime}\left(g_{j}^{L}\right)=\left[\frac{1}{J}+\frac{\lambda}{J} \times \frac{(J-1)}{2}\right], \quad j \in M \\
g_{j}^{L}=0, j \notin M, j \neq a
\end{gathered}
$$

where $\lambda$ is the Lagrange multiplier on the proposal support constraint given by equation 4 . As characterized in equation 5, the proposer internalizes both his district's share of the tax costs $\frac{1}{J}$, as well as the shadow cost $\frac{\lambda}{J}$ for each district in the size $\frac{J-1}{2}$ coalition. While jurisdictions excluded from the coalition are under-provided, public goods are over-provided for either the

\footnotetext{
${ }^{3}$ This section follows Persson and Tabellini (2002).
} 
agenda-setter $(j=a)$, members of the winning coalition $(j \in M)$, or possibly both. ${ }^{4}$ Due to the incentives created by national tax financing of local public goods, the proposer uses his agenda-setting powers in order to misallocate resources for the benefit of his home jurisdiction and/or those jurisdictions represented in the majority coalition. This misallocation comes at the expense of those jurisdictions excluded from the coalition.

\subsection{Universalism}

Consider next the legislative model of universalism due to Weingast, Shepsle, and Johnsen (1981). Given the empirical focus on voting decisions, the model is adapted to incorporate this aspect of the political process. In the first stage, the legislature operates under a mode of universalism; each representative independently chooses spending for their district. Taken together, these choices on the part of representatives form a proposal $\left(\mathrm{g}^{U}\right)$. In the second stage, each representative votes over whether or not to accept this proposal, relative to a zero reversion distribution.

Given a proposal, representatives follow voting rules identical to those of the legislative bargaining model. That is, representatives support proposals under which the benefits accruing to the jurisdiction exceed the tax costs associated with aggregate provision:

$$
h\left(g_{j}^{U}\right) \geq \tau / N
$$

Taking these voting rules as given, each representative chooses spending levels in order to equate marginal jurisdictions benefits and marginal jurisdiction costs:

$$
N h^{\prime}\left(g_{j}^{U}\right)=\frac{1}{J}
$$

Thus, as shown in equation 9, public goods are over-provided, relative to the Samuelson condition, in every jurisdiction. Due to concentrated project benefits and dispersed tax costs, each representative internalizes only their jurisdiction's share of the tax costs.

\section{$4 \quad$ Empirical model}

This section tests for the common pool incentives documented above using the representative voting decision rule in equations 4 and 8 . As demonstrated, this voting rule is consistent with both the legislative bargaining and universalism models and thus does not rely upon either of

\footnotetext{
${ }^{4}$ Specifically, there is no shadow cost $\lambda$ such that both the proposer and winning coalition members are underprovided, relative to the Samuelson conditions. In order for both to be underprovided $\left[N h^{\prime}\left(g_{j}\right) \geq 1\right]$, one can show that $2 \leq \lambda \leq \frac{2}{J+1}$, an obvious contradiction.
} 
the assumed underlying political process. More generally, this voting rule is consistent with any political process in which representatives, through majority voting, have the final authority within the legislature over proposed project allocations.

For estimation purposes, consider the following utility specification:

$$
h\left(g_{j}\right)=\gamma g_{j}^{\alpha}
$$

where $\alpha \in(0,1)$ captures the marginal utility in own-district project spending. The utility parameter $\gamma$ captures preferences for public goods and, while assumed homogenous in the theoretical section, is allowed to vary across jurisdictions empirically:

$$
\gamma_{j}=\exp \left(\theta X_{j}+\sigma \xi_{j}\right)
$$

where the vector $X_{j}$ and scalar $\xi_{j}$ represent observed and unobserved preferences for public spending. Using these two parameterizations in the proposal support condition, given by equations 4 and 8, and allowing population $N_{j}$ and federal tax burdens $\tau_{j}$ to vary across jurisdictions, representative $j$ will support the proposal if the utility benefits accruing to the district exceed its share of the total tax cost:

$$
\exp \left(\theta X_{j}+\sigma \xi_{j}\right) g_{j}^{\alpha} \geq \tau_{j} / N_{j}
$$

Next, assume that, conditional on observed preferences, population, own-district spending and tax costs, unobserved preferences are distributed standard normal $\left[\xi_{j} \mid X_{j}, N_{j}, g_{j}, \tau_{j} \sim N(0,1)\right]$. In this case, representative voting decisions can be expressed as a familiar probit model:

$$
\operatorname{Pr}(\text { support })=\Phi\left[\frac{\theta}{\sigma} X_{j}+\frac{\alpha}{\sigma} \log \left(g_{j}\right)-\frac{1}{\sigma} \log \left(\tau_{j} / N_{j}\right)\right]
$$

where $\Phi$ is the standard normal distribution function. ${ }^{5}$ Typically, the standard deviation of unobserved preferences $(\sigma)$ is normalized to one in Probit models; I have chosen instead to estimate $\sigma$ and to normalize utility to be measured in dollars, as expressed in equation 1.

This voting rule in equation 13 highlights, in a very simple way, the common pool incentives facing legislators. Conditional on tax $\operatorname{costs}\left(\tau_{j}\right)$, the probability of supporting the proposal is increasing in own-district spending $\left(g_{j}\right)$. Countering this preference for higher spending, the probability of supporting the proposal is decreasing in the tax costs associated with aggregate spending $\left(\tau_{j}\right)$, conditional on own-district spending $\left(g_{j}\right)$.

\footnotetext{
${ }^{5}$ Since this probit equation includes the natural log of own-spending, one dollar is added to public spending in all districts to account for zero spending in some districts.
} 
The remainder of this paper uses evidence from Congressional voting over transportation projects to empirically document the responsiveness of legislator choices to such incentives. To the extent that legislators do respond, I will then use the estimated underlying utility parameters $(\alpha, \sigma, \theta)$ to uncover the efficient, or Samuelson, project sizes and the deadweight loss associated with this common pool problem.

\section{Transportation projects}

Implementation of this empirical model requires data on legislator voting records, districtspecific public spending, and the distribution of tax liabilities across jurisdictions. While Congressional votes on authorization or annual appropriation bills seem likely candidates, there are several problems with this approach. First, these types of legislation often have non-fiscal policies attached to public spending provisions. ${ }^{6}$ These provisions tend to have differential effects across jurisdictions and thus induce both specification and measurement error. Second, in the case of authorization or appropriation bills, the assumption of a zero-spending reversion budget is suspect. When these bills fail to pass, spending is typically supplemented by continuing resolutions at prior year levels, while Congress continues the bargaining process. Thus, when deciding whether to support a proposal, legislators trade off the provisions of the bill under consideration with both temporary spending under continuing resolutions and future provisions likely to emerge from ongoing negotiations. Third, federal tax incidence data across geographic entities, such as states or congressional districts, are not readily available. The Tax Foundation (2000) has attempted to estimate the cross-state distribution of total federal tax liabilities. However, in doing so, one encounters thorny issues regarding economic incidence. For example, are the burdens of the corporate income tax borne by its shareholders, customers, or employees, each of whom may reside in different states?

To overcome these obstacles, I focus on votes over an amendment in the U.S. House of Representatives designed to strip away 1,653 transportation projects (totaling $\$ 9.5$ billion) from the Transportation Equity Act for the 21st Century (TEA-21), which was passed in 1998 and authorized transportation spending for 1998-2003. ${ }^{7}$ This stripping amendment failed by a $79-337$ vote and the earmarked projects were included in the final authorization bill. ${ }^{8}$

\footnotetext{
${ }^{6}$ For example, the 1998 transportation reauthorization contained ethanol tax breaks, drunken driving prevention incentives, air bag policies, and a ban on certain trucks.

${ }^{7}$ The amendment also stripped away $\$ 2$ billion in funding for rail transit projects, although the bill did not earmark these funds for specific projects. Rather, the bill listed projects that would be eligible to apply to the Department of Transportation for funding. The Department would then have discretion in allocating these funds. Due to this lack of information, I simply exclude these transit funds from the analysis.

${ }^{8}$ Given that the vote was overwhelmingly in favor of supporting the projects, votes by representatives over
} 
For consistency with the theoretical model, I will refer to the 337 no votes on the stripping amendment as votes in support of the projects and the 79 yes votes on the stripping amendment as votes in opposition of the projects. Regarding the first problem described above, this amendment within the authorization bill had narrow language, restricting consideration to public spending provisions. Second, lending support to the zero spending reversion assumption, had the amendment passed, the projects would likely have not been included in the final legislation, since the Senate version contained no earmarked projects and President Clinton had publicly opposed them. ${ }^{9}$ Of course, were the amendment to pass, these projects could have been included in future legislation, such as the transportation appropriations bill. Since such future legislation is unobserved, we view these considerations as beyond the scope of this study and regard the zero reversion assumption as a reasonable approximation. Regarding the third complication, measurement of tax burdens at the jurisdiction level, transportation projects are funded through a single tax, the federal gasoline tax, and the cross-state distribution of such tax liabilities is readily available. ${ }^{10}$ While there is little formal evidence on the economic incidence of gasoline excise taxes, Poterba (1996) and Besley and Rosen (1999) find a strong relationship between after-tax consumer prices and sales taxes, suggesting that residents of a jurisdiction in which commodity taxes are collected bear a substantial, if not complete, share of the incidence.

\section{Data}

Summary statistics are provided in Table 1. As predicted by the theoretical model, support for funding of these projects is increasing in own-district spending and decreasing in tax burdens. Those districts supporting the projects tend to be smaller, more urban and have longer commute

this amendment may have been one of "position-taking". More specifically, knowing that the amendment would fail, representatives used their votes to signal to constituents whether or not their district was a net beneficiary from the funding of these projects. So long as these signals are accurate, however, votes over the amendment will reflect the costs and benefits of these projects. Of course, representatives may use the vote as an opportunity to signal the benefits and costs of not only the stripping amendment but also of the larger transportation bill. Unfortunately, most of the funds in the larger bill were transferred to state governments, which then decided how to allocate the resources across projects within the state. Thus, it is difficult to measure the benefits of the larger bill across Congressional districts. In the end, this is an empirical question; to the extent that the empirical results do not provide evidence that votes reflect the costs and benefits of these projects, one interpretation is that representatives were sending signals to voters on the larger transportation bill.

${ }^{9}$ Congressional Quarterly Almanac, 1998.

${ }^{10}$ Federal gasoline tax revenues are deposited into the Highway Trust Fund. The 1998 reauthorization discontinued the use of this fund for general deficit reduction, effectively creating a trust fund "firewall", a dollar-fordollar correspondence between gasoline tax revenues and transportation spending. 
times. Regarding industrial composition, those supporting the projects tend to represent districts with employment in transportation and communications and services, which is the omitted category in Table 1, although these differences are quantitatively small. The remainder of this section describes the construction of the two key variables in the empirical analysis: owndistrict spending and tax costs.

\subsection{District project spending}

In order to match each of the projects with a Congressional district, I relied on the project description in the bill. These descriptions provide a city or county name, which could be matched with a district in the Congressional District Atlas (1998). For those cities or counties with multiple districts, I used a variety of additional sources, including maps from the Atlas, testimony before the Subcommittee on Surface Transportation, and press releases from representatives' websites. Approximately 10 percent of project spending could not be assigned to a specific district, either due to the project being located in multiple districts or insufficient information in the project description. Given this lack of information, I simply exclude these projects from the analysis. ${ }^{11}$ Finally, since projects are funded over the 1998-2003 horizon, spending is converted into 1998 dollars using a discount rate of 2.7 percent, the average rate of inflation between 1990 and 1999 .

\subsection{Tax costs}

While the theoretical model assumed that public spending was financed exclusively through central government tax revenues, these transportation projects were funded through a 80 percent federal share and a 20 percent state share; each district's share of the total tax costs of the proposal can thus be expressed as follows:

$$
\tau_{j}=\left(\frac{1}{5}\right) s_{j / s}\left[g_{j}+\sum_{l \in S_{j}} g_{l}\right]+\left(\frac{4}{5}\right) s_{j / s} s_{s / f} G
$$

where $s_{j / s}$ is the district's share of the state costs, $s_{s / f}$ is the state's share of the federal taxes, and $S_{j}$ is the set of other districts within the state. ${ }^{12}$ Each state's share of the federal costs

\footnotetext{
${ }^{11}$ As an alternative measure, I included multiple-district projects but, somewhat arbitrarily, equally allocated the spending between the relevant districts. Results using this measure, not reported here, are similar to the baseline results in this paper.

${ }^{12}$ This expression implicitly assumes that state governments finance their $20 \%$ share through gasoline tax revenues. Per Table SF-1 of Highway Statistics (1998), gasoline tax revenues represent $52 \%$ of own-source revenues attributable to highway spending. Further, the two other largest revenue sources, vehicle taxes (26\%)
} 
$\left(s_{s / f}\right)$ can be calculated using state-specific trust-fund receipts, which are available in Highway Statistics (1998). Unfortunately, each district's share of state revenues $\left(s_{j / s}\right)$ are not available.

I make two attempts to resolve this data limitation. The first approach, described more fully in the next paragraph, uses the cross-state variation in tax liabilities $\left(s_{s / f}\right)$ to estimate the within-state variation $\left(s_{j / s}\right)$. The second approach simply aggregates the two key districtlevel variables, voting decisions and project spending, from the Congressional district-level to the state-level. After matching these measures with the state-level data on tax liabilities, I estimate a grouped linear probability model for the sample of 50 states.

In order to estimate the within-state variation in gasoline tax receipts, I use state-level variation in tax receipts to predict district-level receipts. More specifically, state trust fund receipts are regressed on exogenous state characteristics, and the resulting coefficients are then matched with exogenous district characteristics to predict receipts at the district level. The results from this regression are provided in Table 2. Given my goal to predict aggregate receipts at the district level, which are then converted into shares, all regressors are measured as state aggregates. ${ }^{13}$ Only two coefficients are statistically significant, likely reflecting the small sample of 50 states. However, the R-squared of the regression is 0.9645 , suggesting strong predictive power. Using the predicted district receipts, each district's share of state receipts is given by:

$$
s_{j / s}=\frac{\text { receipts }_{j}}{\text { receipts }_{j}+\sum_{l \in S_{j}} \text { receipts }_{l}}
$$

Although the within-state variation in state tax liabilities is generated from these predicted gasoline tax receipts, it is important to note that two other sources of variation in district gasoline tax receipts in equation 14, namely cross-state differences in project spending and cross-state differences in tax liabilities, are taken from data sources and are thus independent of the results of this prediction approach regarding variation in tax liabilities within states.

Given that users of transportation services pay a disproportionate share of gasoline taxes, unobserved preferences for transportation services may be positively correlated with these measured tax liabilities. To address this concern of benefits taxation, the econometric analysis includes controls for observed preferences for transportation services, such as area, percent urban, commute times, and the composition of employment across industries. However, some and tolls $(8 \%)$, should have incidence distributions that are similar to the distribution for gasoline tax revenues since all three sources tax highway users.

${ }^{13}$ Thus, the receipts equation represents an underlying individual demand for gasoline, which has been aggregated by summing across all state residents. Results from a per-capita specification, not reported here, provide similar results. 
preferences for transportation, such as geography, are difficult to measure. While this positive correlation between unobserved preferences and gasoline tax liabilities may lead to biased parameter estimates, this bias with respect to the tax costs coefficient should, if anything, be upwards and thus against measuring a negative relationship between tax costs and support for funding of these projects.

\section{Empirical results}

\subsection{Probit results}

The results in Table 3 provide the first evidence that legislators respond to common pool incentives to support own-district spending but to oppose tax costs associated with aggregate spending. The first column of Table 3 presents the results of a Probit voting model that includes only the two key independent variables from the theoretical model: log own-district spending and $\log$ tax costs. ${ }^{14}$ As predicted by the theoretical model, the coefficient on own-district spending is positive and statistically significant. While legislators support higher own-district spending, they attempt to restrain aggregate spending and the associated tax costs, as the coefficient on tax costs is negative and statistically significant. These results demonstrate that legislators do act on incentives, which are inherent in a system of local public goods financed from a national tax base, to boost own-district spending while restraining the tax costs associated with aggregate spending. The remainder of this paper provides evidence on the robustness of this result and then, having found that legislators respond to common pool incentives, estimates the efficient allocation of public goods and the deadweight loss associated with this common pool problem.

While the theoretical model does not incorporate heterogeneity in preferences for public goods, such heterogeneity may cast doubt on the assumption that unobserved preferences $\xi_{j}$ are independent of spending proposals. In particular, both legislative processes that were examined predict a positive correlation between preferences for public spending $\left(\xi_{j}\right)$ and owndistrict public spending $\left(g_{j}\right)$, leading to an upward bias in the project spending coefficient. Under legislative bargaining, proposers have an incentive to form coalitions that consist of

\footnotetext{
${ }^{14}$ Bootstrap standard errors, which are provided in table 3 , reflect the additional uncertainty arising from the inclusion of log tax costs, which is a generated regressor. One hundred replications were taken from the set of Congressional districts, and these observations were used in both the first-stage state-level tax receipts regressions and in the second-stage Probit model. To reflect the composition of the bootstrap sample of Congressional districts, state-level observations in the tax receipts regressions were weighted, with the weights equal to the number of within-state Congressional districts that were represented in the bootstrap sample divided by actual number of Congressional districts within the state.
} 
those districts with a stronger preference for public services. ${ }^{15}$ Under a norm of universalism, each representative chooses spending such that the marginal jurisdiction benefit equals the marginal jurisdiction cost; thus, districts with a strong preference for public goods will demand higher spending in their district.

Two approaches are taken to address such endogeneity: inclusion of observable measures of preferences for transportation services and a state fixed effects model. ${ }^{16}$ First, the second column of Table 3 reflects the results of a Probit model that includes the following exogenous district characteristics: area, percent urban, commute times, and industry employment composition variables. The inclusion of these district characteristics, which capture observable heterogeneity in preferences for transportation projects, changes the coefficients on the two key budgetary variables, own-district spending and tax costs, only slightly. Further, none of these preference measures are statistically significant.

\subsection{Fixed effects logit results}

To the extent that unobserved preferences for transportation services vary only across states, the inclusion of state fixed effects will correct for any endogeneity. Although incorporating fixed effects into probit models is not feasible, Chamberlain (1980) provides a fixed effects logit estimator and the third column of Table 3 provides such estimates. Since the estimator uses only variation in votes within states, 126 observations from states without such variation are dropped. Including these fixed effects, the own-spending coefficient remains positive and statistically significant. While the coefficient on tax costs remains negative, it is statistically insignificant, perhaps reflecting the loss in power from both dropping observations and relying exclusively on tax cost variation within states, which is constructed from the state-level tax receipts regressions in Table 2. Finally, the district characteristics are all statistically insignificant in this case.

\subsection{Goodness of fit}

Representative voting decisions may reflect considerations other than the project benefits and associated tax costs. For example, representatives whose districts fared poorly under the proposed allocation of funds may have still supported the committee and its proposal in the

\footnotetext{
${ }^{15}$ See, for example, Chari, Jones, and Marimon (1997) and Coate (1997).

${ }^{16}$ Alternatively, one could use a simultaneous equations probit model. However, it is difficult to identify variables that affect federal spending within the district but not voting decisions of federal representatives. See Knight (2002) for an analysis using the characteristics of federal representatives as an instrument for federal spending in an analysis of spending decisions by state officials.
} 
hopes of securing funds for their district in future legislation. To address this issue, three measures of predictive power, or goodness of fit, are provided. The pseudo R-squared, presented near the bottom of Table 3, ranges between 0.1836 in the fixed effects logit model to 0.2700 for the probit model with exogenous variables. Second, Table 4 provides marginal effects for the two key independent variables. ${ }^{17}$ In the Probit model with exogenous variables, a one-standard deviation increase in the log of own-spending increases the probability of voting yes by 16 percentage points. For tax costs, a one-standard deviation increase decreases the probability of voting yes by 7 percentage points. Finally, the Probit model with exogenous variables correctly predicts the votes for 87 percent of representatives. ${ }^{18}$ In summary, while these project spending and tax cost measures certainly do not explain all of the variation in voting behavior, these three tests suggest that such measures do have effects that are both economically and statistically significant.

\subsection{Additional Robustness Checks}

While project spending and tax costs are both economically and statistically significant determinants of voting behavior, legislator characteristics may also play a role in voting decisions. Table 5 provides results from a Probit model that includes the following legislator characteristics: an indicator variable for party affiliation, tenure (defined as the number of years the representative has served in the U.S. House), and an indicator for chairing a non-transportation committee, which may capture whether or not the representative is a House leader. ${ }^{19}$ As shown, Republicans were significantly less likely to support funding for these projects, suggesting that ideology played an important role. Neither tenure nor chairing a committee significantly affected the results. While party affiliation certainly plays an important role in voting decisions, the coefficient on own-spending remains positive and statistically significant in all cases and the coefficient on tax costs remains negative, although it is statistically insignificant in two out of the three specifications in Table 5.

Having found evidence consistent with the common tax pool problem, a key hypothesized disadvantage to the centralized provision of local public goods, a natural question is whether

\footnotetext{
${ }^{17}$ Marginal effects are not available for the fixed effects logit model since the state fixed effects are not uncovered in the estimation procedure.

${ }^{18}$ Using standard procedures, this analysis predicts that a representative will vote yes if the predicted probability exceeds one-half.

${ }^{19}$ Representation on the transportation authorization committee could not be included in the Probit model because all committee members voted in favor of funding the projects. Rather than including this variable, I estimated the Probit model using only non-committee members in order to evaluate the role of committee membership. The results, not reported here, were qualitatively similar to those in the baseline results, suggesting that committee membership alone is not driving the results.
} 
there are potentially offsetting advantages to centralization. The federalism literature has focused on the ability of centralized governments to internalize cross-jurisdiction spillovers. ${ }^{20}$ Consider next an extended specification of utility from public goods, which allows constituents to receive utility from spending in neighboring jurisdictions:

$$
H\left(g_{j}, \mathbf{g}_{-j}\right)=\gamma g_{j}^{\alpha} \prod_{l \in \Gamma_{j}} g_{l}^{\beta}
$$

where $\Gamma_{j}$ denotes the set of neighbors and $\beta$ captures spillover benefits. ${ }^{21}$ Incorporating spillovers, the Probit model can be expressed as follows:

$$
\operatorname{Pr}(\text { support })=\Phi\left[\frac{\theta}{\sigma} X_{j}+\frac{\alpha}{\sigma} \log \left(g_{j}\right)+\frac{\beta}{\sigma} \sum_{l \in \Gamma_{j}} \log \left(g_{l}\right)-\frac{1}{\sigma} \log \left(\tau_{j} / N_{j}\right)\right]
$$

Neighbors are defined as the set of districts sharing a common border. These borders were identified using the map Congressional Districts of the 105th Congress of the United States (1998). As shown in Table 5, the coefficient on spending in border districts is small and statistically insignificant across all three specifications, suggesting that project spillovers across congressional districts are not substantial. The coefficients on the two key measures, owndistrict spending and tax costs, are similar to those in the baseline results of Table 3.

\subsection{State-level Analysis}

As noted above, data on gasoline tax liabilities are available only at the state level. To address this data limitation, this section provides an analysis in which all three key variables, voting decisions, project spending, and tax liabilities, are measured at the state level. Relative to the analysis at the Congressional-district level, this state-level analysis has several advantages. First, the state-level analysis avoids the need to predict tax liabilities at the district level. Second, even with accurate measures of district tax payments, shopping across Congressional district borders for gasoline may create a divergence between district payments and district incidence. While consumers certainly shop for gasoline across state boundaries, this crossstate shopping is surely less pervasive than cross-border shopping at the Congressional-district

\footnotetext{
${ }^{20}$ Previous empirical analyses of spillovers include Case, Rosen and Hines (1993), who examine state government spending in a decentralized setting and find strong evidence of spillovers, even after allowing for common random shocks among neighbors.

${ }^{21}$ One drawback of this Cobb-Douglass specification is that utility is zero when spending is zero in any of the neighboring jurisdictions. To address this issue, I tried an alternative specification $\left[H\left(g_{j}, \mathbf{g}_{-j}\right)=\gamma g_{j}^{\alpha} G_{-j}^{\beta}\right]$, where $G_{-j}$ is sum, rather than the product, of spending in all neighboring districts. Results using this specification were similar, with $\beta$ positive, but small and statistically insignificant.
} 
level. These advantages of the state-level analysis, however, should be weighed against two possibly offsetting disadvantages, relative to the analysis at the district level. First, there is a loss of information in aggregating data on voting decisions and project spending from the district-level to the state-level. Second, there is a loss in statistical power from the reduction in the sample size from 416 Congressional districts to 50 states.

The following state-level grouped linear probability model is estimated:

$$
\text { E[proportion(support) } \left.)_{s}\right]=\theta \frac{X_{s}}{N_{s}}+\alpha_{1} \frac{g_{s}}{N_{s}}+\alpha_{2} \frac{\tau_{s}}{N_{s}}
$$

where the left-hand side variable is the proportion of representatives from state $s$ supporting the projects and the two key right-hand side variables, state project spending and state tax costs, are at the state level and are measured in per-capita terms. ${ }^{22}$

As shown in Table 6, the simplest specification, which includes only a constant term in the vector of observable characteristics $\left(X_{s}\right)$, is consistent with the results from the Congressional district analysis. Support for funding of the projects among Congressional delegations is increasing in own-state spending but is decreasing in state gasoline tax costs associated with aggregate spending. As a robustness check, column 2 controls for observable state characteristics (area, percent urban, commute times, and the cross-industry composition of employment). In this case, own-spending within the state continues to have a positive and statistically significant effect on Congressional delegation support for the proposal; tax costs continue to have a negative effect, although this result is statistically insignificant, perhaps reflecting the loss in power from the reduction in the sample size from 416 Congressional districts to 50 states. Columns 3 and 4 control for delegation characteristics (proportion Republican, average tenure, and the proportion chairing non-transportation committees). As shown, delegation support for the projects is increasing in state spending in both columns, and this result is statistically significant. The measured relationship between tax costs and delegation support is negative, although the result in the final column, which controls for characteristics of the state as well as characteristics of Congressional delegations, is statistically insignificant.

\section{Welfare analysis}

Theoretical analyses have focused on political inefficiencies in the allocation of local public goods resulting from common tax pool incentives in central legislatures. Having found evidence

\footnotetext{
${ }^{22}$ This model is consistent with the following underlying linear probability model: $\operatorname{Pr}(\operatorname{support})=\theta \frac{X_{j}}{N_{j}}+\alpha_{1} \frac{g_{j}}{N_{j}}+$ $\alpha_{2} \frac{\tau_{j}}{N_{j}}$. Taking state averages of both sides of this linear probability model, and noting that Congressional district populations within states are equal, one can derive the grouped linear probability model in equation 18.
} 
that representatives respond to such common pool incentives at both the Congressional-district level and the state-level, this section uses the parameter estimates from the preceding empirical analysis to test for the existence of and to gauge the magnitude of such inefficiencies in the allocation of public goods.

\subsection{Estimates of Underlying Parameter}

Using equation 13, Probit coefficients can be converted into estimates of the underlying parameters of the theoretical model. For example, the implied value of $\sigma$ is given by inverting the tax cost coefficient and switching the sign. Using the baseline Probit coefficients in Table 3, these implied parameters are given in Table 7 . The implied $\alpha$ ranges from 0.0790 to 0.1318 , suggesting significant diminishment in marginal utility from these transportation projects. Taken together, these implied parameter estimates support the model specification, as $\sigma$ is positive, and $\alpha$ is both positive and lies between zero and unity. Note that these restrictions on the parameter set were in no way imposed by the Probit estimator.

\subsection{Estimates of Samuelson funding levels}

Using parameter estimates from the baseline probit model with exogenous variables, I next calculate the efficient distribution of highway projects. Abstracting from the stochastic component $\left(\xi_{j}=0\right)$, the Samuelson condition in equation 2 is given by:

$$
N_{j} \exp \left(\theta X_{j}\right) \alpha g_{j}^{\alpha-1}=1
$$

Solving equation 19 for own-district spending $\left(g_{j}\right)$ yields the Samuelson project sizes:

$$
g_{j}^{S}=\left[N_{j} \alpha \exp \left(\theta X_{j}\right)\right]^{\frac{1}{1-\alpha}}
$$

These Samuelson project sizes can also be interpreted as those chosen by individual representatives forced to fully internalize the tax costs of public spending in their district.

As shown in Table 8, while those districts represented on the transportation authorization committee received nearly three times the level of spending in other districts, the welfaremaximizing levels are only a fraction higher. Further, while 47 percent of those districts without committee representation were under-provided, only 10 percent of those with committee representation were under-provided. If committee representation confers political power, this welfare analysis confirms the theoretical prediction of the legislative bargaining model, which demonstrated a misallocation from politically weak to politically powerful districts. While several jurisdictions are under-provided, the majority are over-provided and therefore aggregate actual spending of $\$ 7.5$ billion significantly exceeds the $\$ 5.0$ billion aggregate efficient spending. 


\subsection{Deadweight Loss Estimates}

For these over-provided districts, the marginal national costs of provision exceed the marginal national benefits, while the opposite holds for under-provided districts. Figure 1 depicts the deadweight losses associated with this misallocation. This deadweight loss can be expressed analytically as follows:

$$
\mathrm{DWL}=N_{j} \exp \left(\theta X_{j}\right)\left[\left(g_{j}^{S}\right)^{\alpha}-\left(g_{j}\right)^{\alpha}\right]-\left[g_{j}^{S}-g_{j}\right]
$$

The estimated deadweight loss, provided in Table 8 , totals $\$ 7.2$ billion, or 96 cents for every dollar spent on these transportation projects. Even under the maintained assumption of legislators perfectly representing constituent preferences, there is significant deadweight loss from a national perspective due to the incentives created by concentrated project benefits and dispersed tax costs. This estimate is much higher than Inman (1988), who measured deadweight loss at 17 cents for every dollar spent. Inman's lack of cross-sectional data may have caused downward bias in deadweight loss estimates since under-spending districts and over-spending districts tend to cancel out one another when aggregating spending across all districts. On the other hand, the deadweight loss estimate here is potentially overstated here if state or local governments supplemented federal spending for those under-provided districts.

\section{Conclusion}

In summary, this paper uses Congressional votes over transportation project funding in order to test for common pool incentives. This empirical voting analysis is shown to be consistent with the two most commonly-used legislative processes in the theoretical literature and is thus quite general. The empirical results are consistent with legislator reactions to common pool incentives: the probability of supporting funding for these projects is increasing in own-district spending but is decreasing in the tax costs associated with aggregate spending. Having found that legislators do respond to common pool incentives, I then use the parameter estimates to calculate the efficient level of public goods, which suggest over-spending in aggregate, especially in politically powerful districts, and large associated deadweight loss.

While I find significant deadweight loss from federal provision of these transportation services, it is important to note that this critique of centralized provision is specific to the projects under consideration. National networks, such as the interstate highway system or Amtrak, may have more prevalent spillover effects than the projects considered here and may therefore be provided more efficiently in a centralized setting. Similarly, other public policies, such as 
regulations, may exhibit significant uniformity under centralized assignment, a disadvantage of centralization that has been the focus of the economic federalism literature. ${ }^{23}$

Given this caveat, I have found significant costs to centralized provision of these transportation projects. It is often assumed that central governments act as a benevolent social planner, maximizing national welfare. This analysis casts doubt on that assumption, demonstrating that the federal government consists of agents facing incentives to serve local, rather than national, interests. This clash between national and local interests, combined with asymmetries in political power, leads to a misallocation of economic resources from politically weak to politically powerful districts.

\footnotetext{
${ }^{23}$ See Oates (1972 and 1999). Strumpf and Oberholzer-Gee (2001) study liquor regulations, which tend to be set uniformly under centralization. Their primary finding is that states with more heterogeneous preferences tend to decentralize decision-making to local governments.
} 


\section{References}

[1] Reza Baqir. Districting and government overspending. Journal of Political Economy, forthcoming, 2002.

[2] David Baron and John Ferejohn. Bargaining and agenda formation in legislatures. American Economic Review, 77, 1987.

[3] David Baron and John Ferejohn. Bargaining in legislatures. American Political Science Review, 83:1181-1206, 1989.

[4] Timothy Besley and Stephen Coate. Centralized versus decentralized provision of local public goods: A political economy analysis. Journal of Public Economics, forthcoming, 2003.

[5] Timothy Besley and Harvey Rosen. Sales taxes and prices: An empirical analysis. National Tax Journal, 52, 1999.

[6] John Bradbury and Mark Crain. Legislative organization and government spending: crosscountry evidence. Journal of Public Economics, 82, 2001.

[7] Anne Case, James Hines, and Harvey Rosen. Budget spillovers and fiscal policy interdependence: Evidence from the states. Journal of Public Economics, 52, 1993.

[8] Bureau of the Census. Congressional District Atlas, 105th Congress of the United States. 1998.

[9] Bureau of the Census. Congressional Districts of the 105th Congress of the United States. 1998.

[10] Gary Chamberlain. Analysis of covariance with qualitative data. Review of Economic Studies, 47, 1980.

[11] V. Chari, L. Jones, and R. Marimon. The economics of split-ticket voting in representative democracies. American Economic Review, 52, 1997.

[12] Stephen Coate. Distributive policy making as a source of inefficiency in representative democracies. working paper. 1997.

[13] Mark Crain. Districts, diversity, and fiscal biases: Evidence from the american states. Journal of Law and Economics, 42, 1999. 
[14] Alison DelRossi and Robert Inman. Changing the price of pork: the impact of local cost sharing on legislators' demands for distributive public goods. Journal of Public Economics, 71:247-273, 1999.

[15] Tax Foundation. Facts and Figures on Government Finance. Tax Foundation, Inc., 2000.

[16] Thomas Gilligan and John Matsusaka. Deviations from constituent interests: the role of legislative structure and political parties in the states. Economic Inquiry, 33:383-401, 1995.

[17] Robert Inman. Federal assistance and local services in the united states: The evolution of the new federalist fiscal order. In Harvey S. Rosen, editor, Fiscal Federalism: Quantitative Studies. University of Chicago Press, 1988.

[18] Robert Inman and Michael Fitts. Political institutions and fiscal policy: Evidence from the u.s. historical record. Journal of Law, Economics, and Organization, 6:79-132, 1990.

[19] Robert Inman and Daniel Rubinfeld. The political economy of federalism. In Dennis Mueller, editor, Perspectives on Public Choice: A Handbook. Cambridge University Press, 1997.

[20] Robert Inman and Daniel Rubinfeld. Rethinking federalism. Journal of Economic Perspectives, 11, 1997.

[21] Brian Knight. Endogenous federal grants and crowd-out of state government spending: Theory and evidence from the federal highway aid program. American Economic Review, 92, 2002.

[22] Ben Lockwood. Distributive politics and the benefits of decentralization. Review of Economic Studies, forthcoming, 2002.

[23] Wallace Oates. Fiscal Federalism. Harcourt Brace, New York, 1972.

[24] Wallace Oates. An essay on fiscal federalism. Journal of Economic Literature, 37, 1999.

[25] Sam Peltzman. An economic interpretation of the history of congressional voting in the united states. American Economic Review, 75, 1985.

[26] Torsten Persson and Guido Tabellini. Political economics and public finance. In A. Auerbach and M. Feldstein, editors, Handbook of Public Economics, Vol III. Amstredam: New Holland, 2002. 
[27] Keith Poole and Howard Rosenthal. Congress: a political-economic history of roll call voting. Oxford University Press, 1997.

[28] James Poterba. Retail price reactions to changes in state and local sales taxes. National Tax Journal, 49, 1996.

[29] Patrick Sellers. Fiscal consistency and federal district spending in congressional elections. American Journal of Political Science, 41:1024-1041, 1997.

[30] Robert Stein and Kenneth Bickers. Perpetuating the pork barrel : policy subsystems and American democracy. Cambridge University Press, 1995.

[31] Koleman Strumpf and Felix Oberholzer-Gee. Endogenous policy decentralization: Testing the central tenet of economic federalism. Journal of Political Economy, forthcoming, 2001.

[32] U.S. Department of Transportation. Highway Statistics 1998. 1999.

[33] B. Weingast, K. Shepsle, and C. Johnsen. The political economy of benefits and costs: A neoclassical approach to distributive politics. Journal of Political Economy, 89, 1981. 
Table 1

Summary statistics, 416 Congressional districts

(sample averages, standard deviation in parentheses)

\begin{tabular}{|c|c|c|c|c|}
\hline variable & $\begin{array}{l}\text { support projects } \\
\mathrm{N}=337\end{array}$ & $\begin{array}{l}\text { not support } \\
\mathrm{N}=79\end{array}$ & description & source \\
\hline \multicolumn{5}{|l|}{ project spending } \\
\hline $\begin{array}{l}\text { own spending } \\
\left(g_{j}\right)\end{array}$ & $\begin{array}{l}\$ 21,040,860 \\
(17,170,160)\end{array}$ & $\begin{array}{l}\$ 5,743,392 \\
(8,306,591)\end{array}$ & $\begin{array}{l}\text { projects } \\
\text { in district }\end{array}$ & $\begin{array}{l}\text { author } \\
\text { tabulations }\end{array}$ \\
\hline $\begin{array}{l}\text { coalition member } \\
1\left[g_{j}>0\right]\end{array}$ & $\begin{array}{r}0.9169 \\
(0.2764)\end{array}$ & $\begin{array}{r}0.4304 \\
(0.4983)\end{array}$ & $\begin{array}{l}\text { positive spending } \\
\text { in district }\end{array}$ & $\begin{array}{l}\text { author } \\
\text { tabulations }\end{array}$ \\
\hline $\begin{array}{l}\operatorname{tax} \text { cost } \\
\left(\tau_{j}\right)\end{array}$ & $\begin{array}{r}\$ 17,887,410 \\
(\$ 6,198,413) \\
\end{array}$ & $\begin{array}{r}\$ 18,839,510 \\
(\$ 5,170,653) \\
\end{array}$ & $\begin{array}{l}\text { cost of } \\
\text { proposal }\end{array}$ & $\begin{array}{l}\text { author prediction } \\
\text { (see Table 2) }\end{array}$ \\
\hline \multicolumn{5}{|l|}{ demand measures } \\
\hline area & $\begin{array}{r}0.0215 \\
(0.0968)\end{array}$ & $\begin{array}{r}0.0299 \\
(0.0604)\end{array}$ & $\begin{array}{l}\text { millions of } \\
\text { sq. kilometers }\end{array}$ & $\begin{array}{l}\text { Congressional } \\
\text { Districts (Census) }\end{array}$ \\
\hline percent urban & $\begin{array}{r}0.7475 \\
(0.2217)\end{array}$ & $\begin{array}{r}0.7291 \\
(0.2154)\end{array}$ & $\begin{array}{l}\text { percent in } \\
\text { urban area }\end{array}$ & $\begin{array}{l}\text { Congressional } \\
\text { Districts (Census) }\end{array}$ \\
\hline commute time & $\begin{array}{l}10.0588 \\
(2.4523)\end{array}$ & $\begin{array}{r}9.7773 \\
(2.3568)\end{array}$ & $\begin{array}{l}\text { avg. commute } \\
\text { (in minutes) }\end{array}$ & $\begin{array}{l}\text { Congressional } \\
\text { Districts (Census) }\end{array}$ \\
\hline \multicolumn{5}{|l|}{ industry } \\
\hline $\begin{array}{l}\% \text { agriculture } \\
\& \text { mining }\end{array}$ & $\begin{array}{r}0.0337 \\
(0.0319)\end{array}$ & $\begin{array}{r}0.0423 \\
(0.0358)\end{array}$ & $\begin{array}{l}\% \text { employed } \\
\text { in industry }\end{array}$ & $\begin{array}{l}\text { Congressional } \\
\text { Districts (Census) }\end{array}$ \\
\hline $\begin{array}{l}\% \text { construction } \\
\& \text { manufacturing }\end{array}$ & $\begin{array}{r}0.2409 \\
(0.0643)\end{array}$ & $\begin{array}{r}0.2409 \\
(0.0778)\end{array}$ & $\begin{array}{l}\% \text { employed } \\
\text { in industry }\end{array}$ & $\begin{array}{l}\text { Congressional } \\
\text { Districts (Census) }\end{array}$ \\
\hline $\begin{array}{l}\text { \% transportation } \\
\& \text { communication }\end{array}$ & $\begin{array}{r}0.0713 \\
(0.0156)\end{array}$ & $\begin{array}{r}0.0683 \\
(0.0145)\end{array}$ & $\begin{array}{l}\% \text { employed } \\
\text { in industry }\end{array}$ & $\begin{array}{l}\text { Congressional } \\
\text { Districts (Census) }\end{array}$ \\
\hline$\%$ trade & $\begin{array}{r}0.2118 \\
(0.0197\end{array}$ & $\begin{array}{r}0.2171 \\
(0.0190)\end{array}$ & $\begin{array}{l}\% \text { employed } \\
\text { in industry }\end{array}$ & $\begin{array}{l}\text { Congressional } \\
\text { Districts (Census) }\end{array}$ \\
\hline
\end{tabular}


Table 2

Trust Fund Receipts Equation Results, 50 States

Receipts Source: Highway Statistics, 1998 (Table FE-9)

(** $95 \%$ significance, $* 90 \%$ significance)

note: all variables measured as totals across state population

\begin{tabular}{|l|l|}
\hline Variable & Coefficient \\
\hline population & 0.0731 \\
& $(0.0825)$ \\
\hline area & 3800.984 \\
& $(81005.33)$ \\
\hline urban & $-0.0853^{*}$ \\
& $(0.0514)$ \\
\hline commute time & -0.0052 \\
& $(0.0055)$ \\
\hline agriculture \& mining & $2.3447^{* *}$ \\
& $(0.6365)$ \\
\hline construction \& manufacturing & 0.1143 \\
& $(0.2208)$ \\
\hline transportation \& comm. & 1.7484 \\
& $(1.3181)$ \\
\hline trade & 0.7066 \\
& $(0.7976)$ \\
\hline constant & -12301.83 \\
& $(35102.25)$ \\
\hline R-squared & 0.9645 \\
\hline
\end{tabular}


Table 3: Representative voting decisions - baseline specification

\begin{tabular}{|c|l|l|l|}
\hline & P* $95 \%$ significance, $*$ Po sit & \multicolumn{1}{|c|}{ Probit } & FE Logit \\
\hline dep. variable & vote & vote & vote \\
\hline observations & 416 & 416 & 290 \\
\hline $\begin{array}{c}\text { own-spend. } \\
\text { (in logs) }\end{array}$ & $0.1084^{* *}$ & $0.1095^{* *}$ & $0.1544^{* *}$ \\
\hline tax costs & $-0.0131)$ & $(0.0120)$ & $(0.0398)$ \\
\hline in logs) & $(0.4104)$ & $(0.4503)$ & $(2.5665)$ \\
\hline area & & -0.4158 & -5.6771 \\
& & $(3.1059)$ & $(17.9221)$ \\
\hline percent & & 0.0229 & -0.2432 \\
urban & & $(0.7124)$ & $(2.8092)$ \\
\hline commute time & & -0.0265 & -0.1696 \\
& & $(0.0734)$ & $(0.2495)$ \\
\hline \% agriculture & & -1.1717 & 4.7140 \\
\& mining & & $(4.5276)$ & $(21.7876)$ \\
\hline \% constr. & & 0.9759 & 5.1119 \\
\& mfg & & $(1.9343)$ & $(6.7321)$ \\
\hline \% trans. & & 14.5034 & 41.1300 \\
\& comm. & & $(9.4279)$ & $(26.1207)$ \\
\hline \% trade & & -2.7533 & 5.6248 \\
\hline \hline R-squared & 0.2555 & 0.2700 & 0.1836 \\
\hline
\end{tabular}

Table 4: Probit marginal effects - key parameters (** $95 \%$ significance, $* 90 \%$ significance)

\begin{tabular}{|c|c|c|l|}
\hline & Probit & Probit & std. deviation \\
\hline district characteristics & no & yes & \\
\hline $\log$ own-spending & $0.0248^{* *}$ & $0.0245^{* *}$ & 6.3754 \\
\hline $\log$ tax costs & $-0.1937^{* *}$ & $-0.1857^{* *}$ & 0.3776 \\
\hline
\end{tabular}


Table 5

Key parameters

\section{Alternative specifications}

(** $95 \%$ significance, $* 90 \%$ significance, bootstrap standard errors)

\begin{tabular}{|c|c|c|c|c|c|c|}
\hline & Probit & Probit & FE Logit & Probit & Probit & FE Logit \\
\hline dependent variable & vote & vote & vote & vote & vote & vote \\
\hline district characteristics & no & yes & yes & no & yes & yes \\
\hline $\begin{array}{c}\text { own-spending } \\
\text { (in logs) }\end{array}$ & $0.1075^{* *}$ & $0.1101^{* *}$ & $0.1734^{* *}$ & $0.1064^{* *}$ & $0.1079^{* *}$ & $0.1547^{* *}$ \\
$(0.0124)$ & $(0.0132)$ & $(0.0517)$ & $(0.0122)$ & $(0.0123)$ & $(0.0352)$ \\
\hline $\begin{array}{c}\text { tax costs } \\
\text { (in logs) }\end{array}$ & $-0.5001^{*}$ & -0.1760 & -0.0176 & $-0.9500^{* *}$ & -0.9066 & -1.9886 \\
$(0.2911)$ & $(0.4085)$ & $(3.2489)$ & $(0.4178)$ & $(0.4413)$ & $(3.8714)$ \\
\hline republican & $-0.9059^{* *}$ & $-0.9729^{* *}$ & $-2.0951^{* *}$ & & & \\
& $(0.2264)$ & $(0.2658)$ & $(0.7683)$ & & & \\
\hline tenure & 0.0122 & 0.0108 & 0.0356 & & & \\
& $(0.0145)$ & $(0.0158)$ & $(0.0461)$ & & & \\
\hline committee chair & -0.2191 & -0.2392 & -1.2755 & & & \\
\hline neighbor spending & $(0.4036)$ & $(0.5009)$ & $(8.4901)$ & & & \\
(in logs) & & & & 0.0027 & 0.0032 & -0.0036 \\
\hline \hline R-squared & 0.2602 & 0.2742 & 0.1872 & 0.2580 & & \\
\hline
\end{tabular}


Table 6

Key parameters

Grouped (state-level) linear probability models

(** $95 \%$ significance, $* 90 \%$ significance, robust standard errors)

(dependent variable is proportion within delegation supporting project funding, 50 observations)

\begin{tabular}{|c|c|c|c|c|}
\hline state characteristics & no & yes & no & yes \\
\hline delegation characteristics & no & no & yes & yes \\
\hline own-spending & $0.0108^{* *}$ & $0.0106^{* *}$ & $0.0137^{* *}$ & $0.0130^{* *}$ \\
(per-capita) & $(0.0027)$ & $(0.0025)$ & $(0.0027)$ & $(0.0022)$ \\
\hline tax costs & $-0.0170^{* *}$ & -0.0043 & $-0.0204^{* *}$ & -0.0088 \\
(per-capita) & $(0.0046)$ & $(0.0069)$ & $(0.0059)$ & $(0.0070)$ \\
\hline \hline R-squared & 0.4093 & 0.5362 & 0.4908 & 0.5979 \\
\hline
\end{tabular}

Table 7: Implied parameters

\begin{tabular}{|c|l|l|l|l|}
\hline & Probit & Probit & FE Logit & Assumed Range \\
\hline Controls & no & yes & yes & \\
\hline implied $\alpha$ & 0.1281 & 0.1318 & 0.0790 & {$[0,1]$} \\
\hline implied $\sigma$ & 1.1816 & 1.2030 & 0.5117 & {$[0, \infty)$} \\
\hline
\end{tabular}

Table 8

Welfare analysis

(district averages)

\begin{tabular}{|c|r|r|}
\hline & $\begin{array}{r}\text { Committee representation } \\
\mathrm{N}=72\end{array}$ & $\begin{array}{r}\text { No representation } \\
\mathrm{N}=344\end{array}$ \\
\hline Actual spending & $\$ 38,460,510$ & $\$ 13,881,810$ \\
\hline Samuelson spending & $\$ 12,472,150$ & $\$ 11,880,230$ \\
\hline percent over-spend & 90.3 percent & 52.9 percent \\
\hline deadweight loss & $\$ 14,509,140$ & $\$ 17,769,970$ \\
\hline under-spenders & $\$ 13,015,350$ & $\$ 32,855,960$ \\
\hline over-spenders & $\$ 14,670,010$ & $\$ 4,341,781$ \\
\hline
\end{tabular}




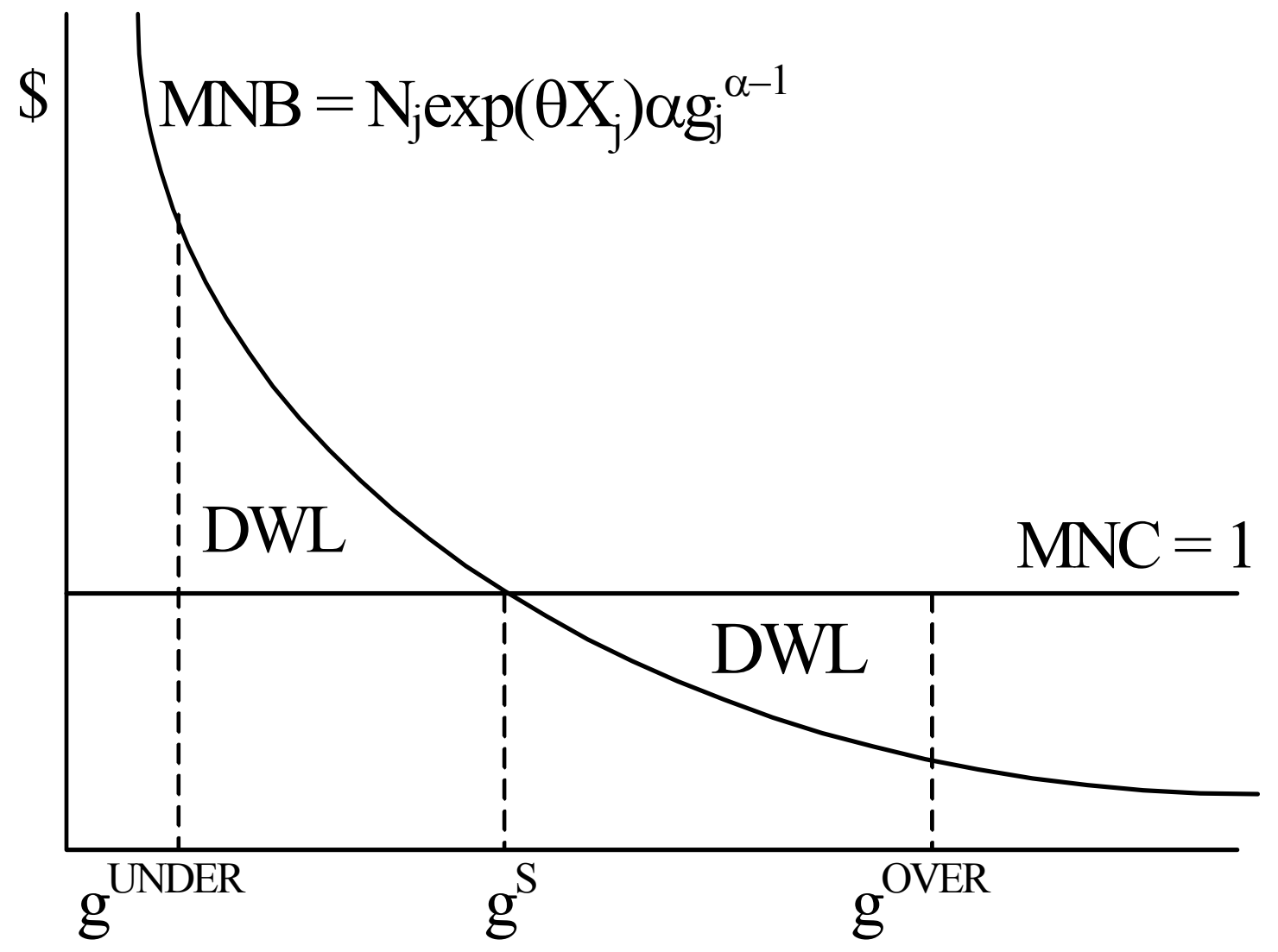

Figure 1: Welfare Analysis 